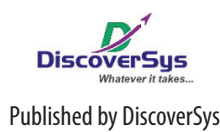

Published by DiscoverSys

\section{Why do HIV-positive pregnant women discontinue with comprehensive PMTCT services? A qualitative study}

Putu Emy Suryanti, ${ }^{1 *}$ Komang Ayu Kartika Sari, ${ }^{2}$ Pande Putu Januraga, ${ }^{2}$ Dinar Lubis ${ }^{2}$
Background and purpose: Prevention of mother to child transmission (PMTCT) is a government program aimed at preventing mother-to-child transmission of HIV. A comprehensive PMTCT program involves the implementation of HIV testing up to antiretroviral (ARV) treatment for mothers with positive HIV test results. Coverage of comprehensive PMTCT remains low, with many HIV-positive pregnant women who discontinued ARV treatment. This study aims to explore the reasons of HIV-positive pregnant women to discontinue with the comprehensive PMTCT program.

Methods: A qualitative study was carried out in Badung District, Bali Province, with seven respondents: one HIV-positive pregnant woman who did not continue the ARV treatment, two HIV-positive women who gave birth the previous year and did not take ARV, three public health centre (PHC) providers, and one head of PHC. Respondents were selected using a purposive sampling technique. Data were collected through in-depth interviews and analyzed thematically. The results presented narratively to illustrate the reasons why HIV-positive pregnant women discontinued with the comprehensive PMTCT program.

Results: The emerging themes related to the reasons of HIVpositive pregnant women discontinued with the comprehensive PMTCT program included the lack of comprehensive PMTCT-related information, the lack of health provider assistance, and the high stigma towards people living with HIV (PLHIV). These barriers were affecting the willingness of HIV-positive pregnant women to continue with the program.

Conclusions: Lack of comprehensive PMTCT-related information, lack of assistance by health care providers, and high public stigma impacts upon HIV-positive pregnant women's willingness to continue with comprehensive PMTCT program. There is a need for a minimum service standard in the implementation of comprehensive PMTCT services and comprehensive information on HIV infection in order to reduce the stigma towards PLHIV.

Keywords: pregnant women, HIV-positive, comprehensive PMTCT, Badung, Bali

Cite This Article: Suryanti, P.E., Sari, K.A.K., Januraga, P.P., Lubis, D. 2018. Why do HIV-positive pregnant women discontinue with comprehensive PMTCT services? A qualitative study. Public Health and Preventive Medicine Archive 6(1): 73-41. D0I:10.15562/phpma.v6i1.13

${ }^{1}$ Mitra Usadha Clinic,

${ }^{2}$ Department of Public Health and Preventive Medicine, Faculty of Medicine, Udayana University
${ }^{*}$ Correspondence to:

Putu Emy Suryanti,

Mitra Usadha Clinic,

emy.b0089@gmail.com

\section{INTRODUCTION}

HIV cases among women in Indonesia through 2015 accounted for $37 \%$ of all HIV cases across the country. ${ }^{1}$ The number of AIDS cases in children infected with HIV from their mothers increased from 48 cases in 2004 to 912 cases in June 2012. ${ }^{2}$ In an effort to anticipate the increase in cases of HIV mother-to-child transmission, the Indonesian Government has implemented the prevention of mother to child transmission (PMTCT) program since 2004. A comprehensive PMTCT program involves the implementation of HIV testing up to anti-retroviral (ARV) treatment for mothers with positive HIV test results. However, since the initiation, the program coverage remains low. The Ministry of Health of Indonesia report shows that until 2012, PMTCT program coverage remains about $6 \%{ }^{3}$ Then in 2013 , the government issued the Regulation of the Ministry of Health of the Republic of Indonesia No. 51 on Guidelines for the Prevention of Mother to Child Transmission of HIV. ${ }^{4}$ Based on these guidelines, the implementation of PMTCT was integrated into antenatal care (ANC) services, on the basis that ANC coverage in Indonesia is quite high at around $97 \%{ }^{4}$

Regarding the coverage of PMTCT in Indonesia, there were 480,061 pregnant women who underwent counseling and/or carried out HIV testing until 2015. Of these, 3,545 HIV-positive pregnant women were identified, while those receiving ARV were 988 or only $28 \%{ }^{1}$ The percentage of HIV-positive pregnant women receiving ARV remains very low, whereas the target of the Ministry of Health is that $100 \%$ of pregnant women who have been tested positive HIV must begin ARV treatment. ${ }^{3}$ Therefore it is important to understand why HIV-positive pregnant women do not continue with the comprehensive PMTCT program.

Badung District reports the second highest HIV/AIDS incidence after Denpasar City in Bali Province. Until 2016, the cumulative number of HIV/AIDS cases was 2.546 or about $16.1 \%$ of total HIV/AIDS cases in Bali. ${ }^{5}$ In 2016, the number of 
pregnant women who had been tested for HIV in Badung was 5,521 people, with $24 \mathrm{HIV}$-positive pregnant women or about $0.43 \% .^{6}$

In this study, the careful selection of respondents is crucial in order to present information that aligns with the purpose of the study. A preliminary assessment in August 2017 in Badung was conducted to identify appropriate respondents with the inclusion criteria: HIV-positive pregnant women or HIV-positive mothers who had given birth the previous year who did not continue with comprehensive PMTCT services (i.e did not take or did not continue ARV treatment). From this assessment, respondents were identified in three PHCs: Petang I, Petang II, and Mengwi II PHCs.

\section{Study framework and procedure}

A qualitative study was carried out to illustrate the reasons why HIV-positive pregnant women did not continue with the comprehensive PMTCT program. In-depth interviews were conducted with seven respondents, namely one HIV-positive pregnant woman who did not continue the ARV treatment, two HIV-positive women who gave birth the previous year and did not take ARV, three PHC providers, and one head of PHC. Respondents was selected using a purposive sampling based on the inclusion criteria, and willingness to participate in the study.

In-depth interviews were conducted by the first author using interview guides in accordance with research objectives. The interview was recorded with a tape recorder, and then transcribed and combined with the researcher's notes during the data collection. Data were securely stored in the researcher's computer using a password.

This study employed a thematic analysis which was done by processing transcripts of interviews manually then coded to facilitate the analysis of information obtained from one respondent with the others. ${ }^{7}$ The analysis results were presented narratively according to the identified pattern and validity of data was ensured through respondents triangulation. ${ }^{8}$ This study has obtained Ethics Clearance from the Human Research Ethics Committee, Faculty of Medicine, Udayana University/Sanglah General Hospital, Denpasar, Bali.

Field Theory was employed as a framework in this study. Field Theory explains that in order to understand and predict one's behaviour, it must be considered that one's personality and environmental factors are interrelated and mutually influencing. ${ }^{9}$ The use of Field Theory in this study can guide researchers to see a complete picture of aspects, both in the individual and the environmental factors, which influence the reasons why
HIV-positive pregnant women dropped out from the PMTCT care.

\section{RESULTS AND DISCUSSION}

There are three themes emerging from the data analysis related to the main reasons of HIV-positive pregnant women to discontinue with comprehensive PMTCT program: lack of information regarding comprehensive PMTCT services particularly the ARV treatment, lack of assistance from health care providers, and the high stigma towards PLHIV.

\section{The lack of comprehensive knowledge on PMTCT}

Interviews with the pregnant women show that there is a paucity of knowledge among HIV-positive pregnant women which is limited to the mode of transmission and prevention of HIV infection. This is evident from the respondent statement as follows:

"I knew a bit about the virus, how it was sexually transmitted, how important it is to wear a condom." (Statement from respondent R-02)

This statement indicates that while they know something about the transmission and prevention of HIV infection, they have not been provided with information on how HIV is treated through ARV. Information on comprehensive PMTCT services received by HIV-positive pregnant women is limited to the prevention of mother-to-child transmission of HIV through non-breastfeeding and referring patients to the hospital for further information:

"They said not to breastfeed and told me to find out more at Kapal Hospital."(Statement from respondent $R-01$ )

This pregnant woman's statement indicates that the PHC provider's information focused on the mother-to-child prevention aspect. The provider simply explained that since the HIV test result was positive, it was recommended to have a follow-up (pre-ARV) test at the hospital. PHC providers did not explain in detail the implementation of comprehensive PMTCT services to respondents. The three respondents were directly referred to the Badung District Hospital (located in Kapal Village), in order to receive more information regarding PMTCT services and to conduct follow up examination. The followings are the respondents' statements related to comprehensive PMTCT services:

"To complete all the follow up tests we were referred to the Kapal Hospital." (Statement from respondent $R-02$ ) 
"We were explained the meaning of HIV reactive, then referred to the Kapal Hospital." (Statement from respondent $R-03$ )

Lack of information obtained by respondents regarding ARV treatment that is part of a comprehensive PMTCT service will affect the respondent's knowledge on the importance of PMTCT care. Comprehensive knowledge may facilitate positive behavior change. ${ }^{10}$ The level of knowledge relates to a person's attitude regarding HIV infection. Comprehensive knowledge of HIV can foster support for the implementation of HIV programs, while low community knowledge about HIV tends to get people to reject the implementation of HIV programs. ${ }^{11}$ Comprehensive knowledge of the importance of ARV treatment as part of comprehensive PMTCT services is expected to influence the attitude of HIV-positive pregnant women in following through with PMTCT.

\section{Support during the PMTCT Care}

Assistance for HIV-positive pregnant women in carrying out ARV treatment varies in each PHC in Badung regency. Based on information obtained from the Petang II PHC provider, if the patient's HIV test result is reactive then the patient will be referred to Badung District Hospital for the follow-up examination. The patient will be accompanied by a healthcare provider, working in collaboration with the Petang II PHC. This assistance facilitated the patient to follow through with further examination in Badung District Hospital. This is supported by the PHC provider's statement:

"After the results have come out and the results are positive we advise the patient to conduct follow up tests accompanied by the provider. The provider is an extension of the support we provide." (Statement from Petang II PHC Provider)

This is confirmed by the R-02 respondent who said she was facilitated to the Badung District Hospital once only at the first time to do a follow-up examination. The following is the statement of the respondent:

"They accompanied me to the hospital once." (Statement from respondent R-02)

In addition to the health providers, PHCs also work with Non Governmental Organizations (NGOs) to provide assistance to HIV-positive pregnant women. This approach is applied in Mengwi II PHC. After the patient's HIV test results are released and the results are reactive, they will be referred to the Badung District Hospital for follow-up examination accompanied by an NGO outreach worker. This is clarified in this PHC provider's statement:

"As soon as someone HIV test is reactive they receive support from the NGO then we refer them to the hospital." (Statement from Mengwi II PHC Provider)

This statement is also supported by R-03 respondent who stated that she was accompanied by an NGO worker when conducting follow up examinations at Badung District Hospital. The following statement refers to this:

"Yes, I asked the NGO worker to accompany me." (Statement from $\mathrm{R}-03$ respondent)

Those kinds of assistance, however, are not implemented in Petang I PHC. HIV-positive pregnant women did not receive assistance from PHC providers nor their networks when carrying out follow-up examination at Badung District Hospital. Assistance by PHC providers is only allocated when there is demand from the patient, as the head of Petang I PHC explains:

"Whenever a mother tests positive we refer them to Kapal Hospital. No one in particular accompanies them, unless they ask for assistance." (Statement from head of Petang I PHC)

This is supported by the R- 01 respondent who explained that she was accompanied only by her father when carrying out further examination at Badung District Hospital. The following statement clarifies:

"My dad accompanied me...." (Statement from respondent $R-01$ )

One of the aspects that support the implementation of comprehensive PMTCT services is the assistance process. The role of assistants in health services can serve as facilitators, brokers, mediators, defenders, and as protectors. ${ }^{12}$ Assistance in the implementation of PMTCT services is the process of facilitating HIV-positive pregnant women to comply with the comprehensive PMTCT program. Support is necessary for a person with HIV especially for HIV-positive pregnant women as HIV is associated with high stigma in the community. Assistance is anticipated to reduce the psychological and social stress that arise in relation to the patient's HIV status and provides foundations for continuing with ARV. 
Studies in Sub-Saharan Africa and Zimbabwe show that the success of a comprehensive PMTCT program was influenced by follow-up and ongoing assistance for at least 24 months after the birth of the infant. ${ }^{13,14}$ In this study, there is a variety of assistance in each PHC for HIV-positive pregnant women in undergoing ARV treatment by health providers and their networks. Different degree of support in each PHC is caused by the absence of minimum service standards in the implementation of PMTCT program for HIV-positive pregnant women.

\section{Stigma towards PLHIV}

HIV and AIDS have historically been associated with diseases caused by bad behaviors such as multiple partnering. Respondents assumed that people with HIV are people who like to keep changing partners. The following is a statement from the respondent:

"It really concerns me, that I will be accused of cheating and going with other men." (Statement from respondent $R-01$ )

This negative assumption about people with HIV impacts upon status disclosure to their families and to the community. Respondents feel ashamed and frightened to share their HIV status even with those close to them. Respondents only disclosed their status to trusted people such as the husband and/or the biological family to avoid stigma from the extended family or community. For example, respondent R-01 disclosed their HIV status only to their biological family (father, mother and sister), while their husbands and in-laws do not know their HIV status because respondents were afraid of the potential negative consequences of disclosure. The following statement illustrates this:

"The husband and in-laws do not know. The poor child if they do. My father knows though." (Statement from respondent R-01)

In contrast to R-01 respondent, R-02 and R-03 respondents shared their HIV status only to their husbands while their in-laws and extended did not know their HIV status. The following quote explains this:

"The husband knows but the family doesn't." (Statement from respondent $R$-02)

"Yes my husband knows. But the extended family doesn't." (Statement from respondent R-03)
The high stigma of the community towards a person with HIV greatly influences the respondent's attitude towards their HIV status. Furthermore, acceptance of an HIV-positive status is closely related to the success of advanced treatment for HIV-positive pregnant women. It would be chllenging to implement PMTCT program if HIV-positive pregnant women did not reveal their HIV status with those close to them. The findings of this study are in accordance with a study in Semarang-Central Java which found that the openness of HIV-positive pregnant women with close couples or families is expected to help HIV-positive pregnant women in receiving support from families and facilitate access to PMTCT services. ${ }^{15}$

In some areas of the Badung District, people remains to assume that HIV infection is an infection created by negative and 'bad' behaviours. Although there have been frequent information disseminations in local neighbourhoods covering HIV, people continue to view someone with HIV as 'bad', and stigma is rife. One of the impacts of community stigma towards people living with HIV is that people are afraid to interact with someone with HIV, especially people who do not understand how HIV is transmitted. This is reflected in this PHC provider's statement:

"Those who do not understand transmission modes still feel afraid, frightened around people with HIV...Yes, stigma is still a problem."

(Petang II PHC provider)

In addition to feeling afraid to interact with someone with HIV, this high stigma also affects people's acceptance of someone with HIV. Some people remains unable to accept someone with HIV around them. The following statement of Head of Petang I PHC supports this:

"Society still doesn't really accept people with HIV. In fact, there was one patient here who was pregnant and people discovered she was $\mathrm{HIV+}$, and she gave birth, and straight after her husband divorced her, forced her to go back to her village, and the child taken from her by the husband's family. The level of stigma is still so high." (Head of Petang I PHC)

Community social acceptance of someone with HIV is still very complicated, and the cause being stigma and widespread negative labelling. ${ }^{16}$

Stigma against a person with HIV-positive will decline as the knowledge and understanding of HIV increases. As stated by the PHC provider at Mengwi II that people in their work area have had better knowledge regarding HIV infection after 
receiving information, and stigma has been mitigated. The following reflects this:

"People are becoming increasingly aware and more and more understand. HIV-positive patients are no longer ostracized, people are more open and aware." (Mengwi II PHC provider)

Increasing knowledge about HIV becomes very important in mitigating stigma towards people with HIV. Villagers are less likely to be exposed to HIV information than are urban residents. ${ }^{11}$ The results of this study indicate that the high stigma towards a person with HIV influences the decision of pregnant women in continuing with the PMTCT program. The stigma of HIV is affected by the values in society and the lack of knowledge about HIV itself. Attitudes and resilience in continuing HIV care are also influenced by social aspects such as the values that evolve in society. ${ }^{17}$

\section{Study limitations and implications}

The limitation of this study is that researchers were unable to involve the families of the respondents, such as husbands and parents as groups, which are essential in ensuring the implementation of comprehensive PMTCT care efforts. This is due to the lack of openness of respondents related to their HIV status. In addition, this study is yet able to describe how instrumental was the role of the familial network in PMTCT program implementation.

The implementation of PMTCT program is a very complex issue, which includes biomedical, behavioural, and social determinants. Therefore, an effective PMTCT program requires a policy that covers all three aspects. HIV infection remains a sensitive issue in society. The high stigma in society towards HIV affects a person's behavior regarding access to health services. HIV-related information, education and communication are needed to improve understanding and change the perception of people regarding HIV and PLHIV. Through reduced stigma it is hoped that someone with HIV can access health services without shame and social discrimination.

In addition, there is a need for a minimum service standard in PMTCT program related to follow-up and continuous facilitation that serves to support a person with HIV, especially HIV-positive pregnant women, navigate available services and ensure success of therapy.

\section{CONCLUSION}

The lack of comprehensive PMTCT-related information, lack of assistance from healthcare providers, and high societal stigma towards PLHIV fosters unwillingness for HIV-positive women to continue with the comprehensive PMTCT program. There is a need for a minimum service standard in the implementation of comprehensive PMTCT services and comprehensive information on HIV infection in order to reduce the stigma towards PLHIV.

\section{ACKNOWLEDGEMENT}

We would like to thank all respondents and the staff of Petang I, Petang II, and Mengwi II PHCs in Badung District who have supported the implementation of this study.

\section{REFERENCES}

1. Ministry of Health of Indonesia. Kajian Epidemiologi HIV Indonesia 2016 (Epidemiological Review of HIV in Indonesia). Ministry of Health of Indonesia. Jakarta. 2017.

2. Ministry of Health of Indonesia. Integrasi Program PMTCT di pelayanan kesehatan ibu dan anak. Dalam: Peranan bidan dalam mendukung pencegahan penularan HIV dari ibu ke bayi (Integration of PMTCT Program into the mother and child health services. In: The roles of midwives in supporting the prevention of mother to child transmission). Ministry of Health of Indonesia. Jakarta. 2012.

3. The Ministry of Health of Indonesia. Rencana aksi nasional pencegahan penularan HIV dari ibu ke anak (PMTCT) Indonesia 2013-2017 (The Indonesia 2013-2017 national action plan on the prevention of mother to child transmission (PMTCT)). Ministry of Health of Indonesia. Jakarta. 2013.

4. Ministry of Health of Indonesia. Peraturan Menteri Kesehatan Republik Indonesia No. 51 Tahun 2013 tentang Pedoman Pencegahan Penularan HIV dari Ibu ke Anak (The Regulation of the Ministry of Health of the Republic of Indonesia No. 51 on Guidelines for the Prevention of Mother to Child Transmission of HIV). 2013. pp: 1-43.

5. Bali Provincial AIDS Comission. Situasi kasus HIV/AIDS di Provinsi Bali (Current situation on HIV/AIDS in Bali). Bali Provincial AIDS Comission. 2016.

6. Wirawan. Kajian epidemi HIV-AIDS cenderung menurun (A review in HIV epidemic that tends to decrease). 2017.

7. Boyatzis, RE. Transforming qualitative information. California: SAGE Publications. 1998.

8. Sugiyono. Metode penelitian kuantitatif kualitatif dan R\&D (Quantitative and qualitative research methods, and R\&D). Bandung: Alfabeta. 2010.

9. The Tavistock Institute. Kurt Lewin-'Field Theory Rule'. Available at: http://www.tavin stitute.org/projects/ field-theory-rule/(2008).

10. Widodo. Pengetahuan, sikap, dan perilaku tentang kehamilan, persalinan serta komplikasinya pada ibu hamil non primigravida di RSUPN Cipto Mangunkusumo (Knowledge, attitude, and behavior on pregnancy, parturient and the complications among non-primigravida pregnant women at The Cipto Mangunkusumo National Central General Hospital). Majalah Kedokteran Indonesia. 2005.

11. Oktarina, Hanafi F, Budisuari, MA. Hubungan antara karakteristik responden, keadaan wilayah dengan pengetahuan, sikap terhadap HIV/AIDS pada masyarakat Indonesia (The association between respondents and geogra-phics characteristics with knowledge and attitude towards HIV/AIDS in Indonesia community). Buletin Penelitian Sistem Kesehat-an. 2009; 124: 362-369. 
12. Latifah D, Mulyana N. Peran pendamping bagi orang dengan HIV/AIDS (ODHA) (The roles of buddies for people living with HIV/AIDS (PLHIV)). In: Prosiding KS: Riset \& PKM. 2014. pp: 306-311.

13. Homsy J, King R, Balaba D, Kabatesi, D. Traditional health practitioners are key to scaling up comprehensive care for HIV/AIDS in Sub-Saharan Africa. AIDS. 2004; 18(12): 1723-1725.

14. Perez F, Mukotekwa T, Miller A, et al. Implementing a rural Programme of PMTCT of HIV in Zimbabwe: First 18 months of experience. Tropical Medicine and International Health. 2004; 9(7): 774-783.

15. Anindita M, Shaluhiyah Z. Non disclosure of HIV-positive status of women to their partner: implication for PMTCT. Jurnal Promosi Kesehatan Indonesia. 2013; 8(1): 39-48.

16. Wahyuni, S. Kepatuhan ibu pada kehamilan, persalinan dan nifas dalam pelaksanaan program pencegahan penularan HIV (The compliance of mothers during pregnancy, delivery and post-delivery in the prevention of HIV transmission program implementation). Jurnal Kebidanan dan Keperawatan Aisyiyah. 2016; 12(1): 38-45.
17. Ritzer G, Goodman DJ, Nurhadi. Teori Sosiologi : dari Teori Sosiologi Klasik sampai perkembangan mutakhir Teori Sosial Postmodern (Sociology Theory: From Classical Sociology Theory until the current development of Postmodern Social Theory). Yogyakarta: Kreasi Wacana. 2010

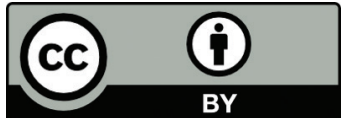

This work is licensed under a Creative Commons Attribution 